Sains Malaysiana 50(8)(2021): 2419-2431

http://doi.org/10.17576/jsm-2021-5008-23

\title{
Pemegunan Bahan Radioaktif dalam Enap Cemar Minyak menggunakan Kaca sebagai Kaedah Alternatif
}

(Solidification of Radioactive Materials in Oil Sludge using Glass as Alternative Method)

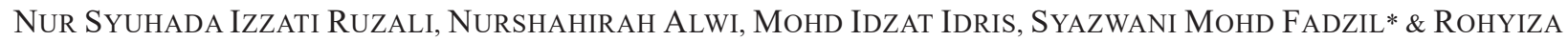 \\ BA'AN
}

\begin{abstract}
ABSTRAK
Enap cemar minyak dikategorikan sebagai bahan radioaktif peringkat rendah dan pelupusan sisa ini menjadi isu penting dalam pengurusan sisa. Oleh itu, kajian ini bertujuan untuk menguruskan bahan radioaktif tabii (NORM) yang terkandung dalam sisa enap cemar minyak melalui kaedah pengacaan dan mengkaji kadar larut lesap bahan dipegun sebelum dilupuskan. Kajian mendapati bahawa sisa muatan yang optimum bagi bentuk sisa kaca adalah pada julat $20-25 \%$ bt. sisa enap cemar dan 75-80\% bt. sisa kaca CRT yang dibakar pada suhu $1200^{\circ}$ C. Ujian XRD menunjukkan kesemua bentuk sisa kaca adalah kebanyakannya amorfus dan unsur-unsur bertabur dengan sekata melalui analisis FESEM-EDX. Tambahan pula, pembebasan ternormal adalah rendah dan tidak melebihi nilai penunjuk yang dijadikan rujukan. Bentuk sisa kaca yang terhasil dalam kajian ini menunjukkan kaedah pengacaan boleh menjadi alternatif bagi pelupusan sisa enap cemar minyak yang mengandungi bahan radioaktif.
\end{abstract}

Kata kunci: Bahan radioaktif tabii; enap cemar minyak; kaca CRT; pemegunan sisa

\section{ABSTRACT}

Oil sludge is categorized as a low-level radioactive material and the disposal of waste is a very important issue in the waste management. Therefore, this study aims to manage naturally occurring radioactive materials (NORM) that contained in oil sludge through vitrification process and investigate the chemical durability of CRT glass before disposal. So, the range of 20-25 wt\% of sludge and 75-80 wt\% of CRT at $1200^{\circ} \mathrm{C}$ were the optimum waste loading. All the glass waste form had mostly amorphous phase and the elements were evenly distributed through FESEM-EDX analysis. Furthermore, the chemical durability of CRT was low and below the standard limit. As conclusion, CRT glass is suitable to use in the vitrification process for treating the oil sludge before disposal in Malaysia.

Keywords: CRT glass; NORM; oil sludge; waste solidification

\section{PENGENALAN}

Di Malaysia, industri perlombongan minyak dan gas merupakan industri penting sebagai sumber tenaga fosil dan menyumbang kepada pembangunan ekonomi negara (Malaysian Investment Development Authority 2015). Hasil industri ini digunakan dalam bidang pengangkutan dan juga sebagai sumber bahan api untuk memasak di negara-negara sedang membangun.
Industri petroleum di Malaysia dikendalikan dan dibangunkan oleh Petroliam Nasional Berhad (PETRONAS) yang berusaha menambahkan kapasiti pengeluaran minyak mentah dengan kepentingan perniagaan di 31 buah negara disebabkan permintaan minyak yang tinggi (UKEssays 2018). Seiring dengan peningkatan pengeluaran minyak mentah, maka secara tidak langsung kadar bahan buangan enap cemar minyak yang terhasil daripada pemprosesan 
minyak juga meningkat. Secara puratanya, penghasilan sisa enap cemar di Malaysia mencecah hampir 50,000 tan metrik pada setiap tahun disebabkan peningkatan kilang penapisan dan pengangkutan minyak di bahagian Selat Melaka (Keshavarzifard et al. 2014). Manakala, dianggarkan hampir satu billion tan enap cemar minyak dihasilkan di seluruh dunia (Hu et al. 2015).

Enap cemar minyak mengandungi bahan radioaktif tabii (NORM) seperti uranium (U-238), torium (Th232) dan progeninya seperti radium-226 (Ra-226) dan radium-228 (Ra-228) serta hidrokarbon yang tinggi (Zaidan 2010). Sisa ini dikelaskan sebagai sisa radioaktif peringkat rendah dan sisa berjadual yang mengandungi unsur-unsur seperti nitrogen $(\mathrm{N})$, fosforus $(\mathrm{P})$, ferum $(\mathrm{Fe})$, kuprum $(\mathrm{Cu})$, kalsium $(\mathrm{Ca})$, magnesium $(\mathrm{Mg})$, kadmium $(\mathrm{Cd})$, fosfat $\left(\mathrm{PO}_{4}^{3-}\right)$, kromium $(\mathrm{Cr})$, zink $(\mathrm{Zn})$, natrium (Na) dan plumbum (Pb) (Suganya et al. 2019) dan perlu dilupuskan mengikut prosedur yang telah ditetapkan oleh badan penguatkuasa bahan radioaktif serta persetujuan dan keizinan daripada pihak Jabatan Alam Sekitar (Mohamad Puad \& Muhd Noor 2003).

Enap cemar minyak ini mengandungi bahan toksik yang tinggi, menyumbang kepada pencemaran alam sekitar dan boleh membahayakan kesihatan manusia serta hidupan lain jika tidak dilupuskan mengikut prosedur yang betul (International Association of Oil and Gas Producers 2016). Ketoksikan ini boleh mengganggu sifat fizikal dan kimia yang boleh mengubah morfologi tanah. Sebagai contoh, enap cemar minyak mempunyai kelikatan yang tinggi dilupuskan ke dalam tanah dan akan diserap masuk ke dalam liang-liang tanah tersebut. Ini mengakibatkan tanah di kawasan tersebut kurang subur seperti tidak berlakunya pencambahan biji benih, menghalang pertumbuhan pokok-pokok dan kekurangan nutrien. Selain itu, unsur-unsur logam berat yang terkandung dalam enap cemar minyak juga akan mengehadkan pertukaran air/udara dan mengurangkan ketersediaan air pada permukaan tanah. Seterusnya, kandungan hidrokarbon dalam enap cemar minyak boleh mengurangkan aktiviti enzim tanah dan memberi kesan toksik kepada mikroorganisma tanah serta merosakkan struktur tanah untuk jangka masa yang panjang. Ketoksikan sisa ini menjadi lebih buruk apabila berlakunya hujan lebat, yang boleh menyebabkan ketoksikan daripada tanah mengalir ke dalam sungai dan laut. Hal ini mampu mengancam kehidupan haiwan (akuatik dan darat) serta seterusnya, membahayakan kesihatan manusia apabila berlakunya keracunan makanan
(International Association of Oil and Gas Producers 2016).

Terdapat beberapa kaedah yang telah digunakan di Malaysia dalam menguruskan sisa enap cemar minyak ini. Kebiasaannya, enap cemar minyak disimpan di dalam tong untuk dilupuskan (Amran et al. 2000; Omar et al. 2004), kaedah penimbusan tanah (Mohd Fadzil et al. 2011; Omar 2019), pengekstrakan dan pembakaran yang bertujuan untuk mengurangkan jumlah enap cemar minyak dan kepekatan hidrokarbon yang terkandung di dalamnya (Omar 2019). Keberkesanan kaedah ini telah dibuktikan melalui kajian terdahulu, namun masih terdapat kekangan dan kekurangan dalam rawatan tersebut seperti memerlukan tempoh perawatan yang lama, kos operasi yang tinggi, memerlukan kawasan atau ruang yang lebih besar. Selain itu, kaedah tersebut masih mempunyai risiko pencemaran terhadap persekitaran disebabkan oleh larut lesap unsur logam (Mohd Fadzil et al. 2011) dan radionuklid yang terkandung di dalam enap cemar.

Justeru, proses pemegunan telah dipilih dalam kajian ini bagi membolehkan sisa enap cemar minyak dan sisa radioktif yang sesuai dilupuskan dengan selamat untuk mengatasi masalah kawasan penyimpanan sisa yang terhad serta mengurangkan dedahan kepada para pekerja. Pemilihan ini bergantung kepada sifat fizikal dan kimia sisa serta kriteria penerimaan bagi kemudahan penyimpanan dan pelupusan jangka panjang. Pemegunan ini dilaksanakan menggunakan teknik pengacaan (vitrification), iaitu pemejalan sisa (waste solidification) dengan menggunakan kaca sebagai medium pemegunan. Hal ini demikian kerana kaca mempunyai matriks yang berupaya memejalkan sisa radioaktif melalui ikatan kimia atau pengkapsulan dengan ketahanan kimia yang sangat tinggi (Mohd Fadzil et al. 2015). Teknik ini dikatakan lebih relevan dari pelbagai aspek termasuk sisa radioaktif peringkat rendah kerana mempunyai ketahanan hakisan terhadap pelbagai keadaan persekitaran dan kestabilan unsur berdasarkan jangka hayatnya dalam tempoh yang lama, kebolehgunaan yang tinggi bagi pelbagai jenis industri dan sisa, penjimatan kos pengurusan sisa dan pengurangan jumlah sisa yang tinggi (sehingga pengurangan sebanyak $97 \%$ berbanding alternatif yang biasa digunakan) (Ojovan \& Batyukhnova 2007).

\section{KAEDAH KAJIAN}

Sampel yang akan digunakan dalam kajian ini ialah enap cemar minyak yang merupakan sisa radioaktif peringkat 
rendah yang diperoleh daripada pusat penyimpanan sementara di Agensi Nuklear Malaysia, Bangi, Malaysia. Manakala, perumah kaca yang digunakan ialah sisa kaca tiub sinar katod (CRT), dibekalkan oleh syarikat industri iaitu Nippon Electric Glass (NEGM) Sdn. Bhd. Sisa kaca ini dikenali sebagai e-sisa yang banyak dijumpai dalam peralatan elektrik dan elektronik serta mengandungi bahan bertoksik yang boleh memudaratkan kesihatan manusia dan alam sekitar jika tidak dilupuskan dengan cara yang betul.

Secara keseluruhan, kaedah kajian dibahagikan kepada empat fasa. Pertama, penyediaan sampel dengan sampel enap cemar dan kaca CRT dihaluskan agar percampuran setiap komposisi lebih sempurna. Enap cemar minyak yang berbentuk separa pepejal, berlumpur pekat dan berminyak serta berwarna kehitam-hitaman perlu dikeringkan terdahulu di dalam relau konvensional selama beberapa hari pada suhu $80^{\circ} \mathrm{C}$ sehingga mencapai berat malar. Kemudian, kesemua sampel (enap cemar minyak dan CRT) dihancurkan menggunakan lesung dan anak lesung serta ditapis bagi mendapatkan sampel yang homogen dan bentuk serbuk yang lebih halus.

Kedua, sampel akan menjalani proses pencirian kimia melalui analisis spektrometer jisim gandingan plasma teraruh (ICP-MS). Analisis ini bertujuan untuk mengenal pasti kepekatan unsur yang terkandung dalam bahan untuk menghasilkan bentuk sisa kaca pegun. Setiap data yang diperoleh perlu dihitung semula kepada berat asal sampel dengan menggunakan (1) (United States Department of Agriculture 2018).

$$
\rho\left(\frac{\mu g}{k g}\right)=\frac{c\left(\frac{\mu g}{L}\right) \times V(L)}{M(k g)}
$$

dengan $\rho$ ialah kepekatan sampel $(\mu \mathrm{g} / \mathrm{kg})$; c ialah data sampel yang diperoleh daripada ICP-MS $(\mu \mathrm{g} / \mathrm{L}) ; \mathrm{V}$ ialah isipadu sampel (L); dan M ialah jisim sampel (kg).

Ketiga, proses pemegunan sisa melalui pengacaan sampel dijalankan menggunakan kaedah pembakaran. Sampel enap cemar minyak (dilabel sebagai EC) dan kaca CRT ditimbang dengan menggunakan penimbang elektronik mengikut komposisi peratus berat (\% bt.) yang ditetapkan (Jadual 1) dan dibakar pada suhu 1100 dan $1200^{\circ} \mathrm{C}$ selama 1-2 jam menggunakan relau pada suhu yang tinggi. Kemudian, sampel dikeluarkan dan disejukkan pada suhu bilik sebelum penilaian dan analisis ke atas bentuk sisa kaca pegun dilakukan. Julat penggunaan enap cemar dan kaca CRT adalah masingmasing sebanyak $20-30 \%$ bt. dan $70-80 \%$ bt.

JADUAL 1. Komposisi bentuk sisa kaca pegun pada suhu yang berbeza

\begin{tabular}{ccc}
\hline Komposisi sampel & \multicolumn{2}{c}{ Suhu $\left({ }^{\circ} \mathrm{C}\right)$} \\
\cline { 2 - 3 } $20 \%$ bt. EC $+80 \%$ bt. CRT & $\checkmark$ & 1100 \\
$25 \%$ bt. EC $+75 \%$ bt. CRT & $\checkmark$ & $\checkmark$ \\
$30 \%$ bt. EC $+70 \%$ bt. CRT & & $\checkmark$ \\
\hline
\end{tabular}

Akhir sekali, penilaian bentuk akhir sisa kaca pegun dijalankan melalui tiga analisis, iaitu pembelauan sinar-X (XRD), mikroskopi elektron pengimbas dengan spektroskopi serakan tenaga sinar-X (FESEM-EDX) dan ujian ketahanan produk (PCT). Penilaian ini bertujuan untuk mengkaji prestasi bentuk sisa kaca pegun yang terhasil selepas proses pengacaan dengan membandingkan komposisi dan suhu yang berbeza. 
Analisis XRD bertujuan untuk menentukan kehadiran fasa hablur dalam bentuk sisa kaca pegun yang berkemungkinan terhasil semasa pembakaran dan penyejukan sampel. Manakala, FESEM-EDX pula bertujuan untuk mengkaji morfologi permukaan bentuk sisa kaca pegun dan mengenal pasti taburan unsur pada permukaan kaca. Analisis ini menggunakan model Merlin Compact yang beroperasi pada voltan pemecut $15 \mathrm{kV}$.

Analisis terakhir lebih memfokuskan kepada pencirian kimia bahan menggunakan PCT yang merupakan salah satu ujian piawai penting dalam menilai ketahanan kimia sebarang bentuk sisa radioaktif pegun sebelum dilupuskan. Analisis ini dijalankan mengikut prosedur American Standard Test Method (ASTM 2002) untuk menentukan kadar maksimum pelepasan ion $\mathrm{Na}$, $\mathrm{B}$ dan Si ke dalam larutan bagi mengukur ketahanan kimia bentuk sisa akhir kaca. Anggaran kadar pelepasan ion dihitung menggunakan pembebasan ternormal $\left(\mathrm{g} / \mathrm{m}^{2}\right)$ dalam (2) (ASTM 2002).

$$
\mathrm{NR}=\frac{\mathrm{C} f}{(f) \cdot\left(\frac{S A}{V}\right)}
$$

dengan NR ialah pembebasan ternormal, $\left(\mathrm{g} / \mathrm{m}^{2}\right) ; \mathrm{C}_{f}$ ialah kepekatan unsur akhir, (g/L); $f$ ialah pecahan unsur dalam bentuk sisa yang tidak tercemar; dan SA/V ialah luas permukaan bentuk sisa akhir dengan isipadu larutan, $\left(\mathrm{m}^{2} / \mathrm{L}\right)$

\section{HASIL DAN PERBINCANGAN}

\section{KEPEKATAN UNSUR ENAP CEMAR MINYAK DAN KACA} CRT

Sampel tersebut dilarutkan pada nisbah 1:10 (enap cemar minyak: larutan asid) selama 45 min dengan menggunakan sistem penghadam gelombang mikro. Kemudian, sampel dihantar untuk menjalani analisis ICPMS dan kepekatan unsur ditunjukkan dalam Jadual 2.

JADUAL 2. Kepekatan unsur dalam enap cemar minyak dan kaca CRT (mg/kg)

\begin{tabular}{ccc}
\hline Unsur & Enap cemar minyak & CRT \\
\hline $\mathrm{Si}$ & $15.16 \pm 3.67$ & $132.86 \pm 2.11$ \\
$\mathrm{Ti}$ & $6.96 \pm 2.09$ & $2.84 \pm 0.51$ \\
$\mathrm{Fe}$ & $1200.28 \pm 37.35$ & $70.81 \pm 14.60$ \\
$\mathrm{Al}$ & $87.77 \pm 59.58$ & $45.18 \pm 3.58$ \\
$\mathrm{Ca}$ & $204.61 \pm 8.05$ & $339.04 \pm 46.71$ \\
$\mathrm{U}$ & $0.05 \pm 0.04$ & - \\
$\mathrm{Th}$ & $8.41 \pm 6.02$ & - \\
$\mathrm{K}$ & $55.62 \pm 28.51$ & $770.87 \pm 14.66$ \\
$\mathrm{Mg}$ & $66.38 \pm 0.80$ & $57.29 \pm 4.46$ \\
$\mathrm{Na}$ & $41.57 \pm 5.76$ & $1587.61 \pm 28.34$ \\
$\mathrm{~B}$ & - & $121.07 \pm 1.28$ \\
$\mathrm{Ba}$ & - & $16.72 \pm 2.84$ \\
$\mathrm{Ce}$ & - & $5.93 \pm 1.40$ \\
$\mathrm{~Pb}$ & - & $212.98 \pm 2.03$ \\
$\mathrm{Sr}$ & - & $14.49 \pm 2.16$ \\
$\mathrm{Zn}$ & - & $30.60 \pm 2.10$ \\
$\mathrm{Zr}$ & - & $1.76 \pm 0.42$ \\
\hline
\end{tabular}


Analisis ICP-MS menunjukkan bahawa enap cemar mengandungi pelbagai unsur dengan kepekatan unsur yang tinggi, iaitu Fe, diikuti $\mathrm{Ca}, \mathrm{Al}$ dan Na. Kebiasaannya, kandungan $\mathrm{Fe}$ yang tinggi boleh dikaitkan dengan kakisan yang berlaku di dasar tangki dan saluran pemprosessan (Gallego et al. 2007). Selain itu, unsur seperti Si dan Al boleh dijumpai dalam kandungan tanah (Liu et al. 2019), manakala kandungan $\mathrm{Na}$ pula hadir disebabkan oleh lokasi pengekstrakan sampel di dasar laut (Meor et al. 2007).

Secara umumnya, kaca CRT terdiri daripada pelbagai unsur yang berbahaya yang memberi kesan kepada alam sekitar dan kesihatan manusia seperti barium (Ba), strontium ( $\mathrm{Sr}$ ) dan $\mathrm{Pb}$, iaitu masing-masing sebanyak 1.96-8.92\%, 2.99-8.57\% dan 0-24.17\% (Karaahmet $\&$ Cicek 2019). Yot dan Mear (2011) juga mendapati bahawa terdapat tiga jenis unsur yang terkandung dalam CRT, iaitu unsur $\mathrm{Pb}(21-24 \%)$ yang terletak di bahagian leher dan corong TV, manakala unsur $\mathrm{Ba}$ dan $\mathrm{Sr}$ pula terletak di bahagian skrin monitor TV (9-13\%). Oleh itu, unsur-unsur ini haruslah dirawat terlebih dahulu melalui beberapa kaedah untuk mengekstrak unsur berbahaya ini sebelum dikitar semula (Fernandes et al. 2013).
Antaranya, penggunaan reagen $\mathrm{Na}_{2}$ EDTA, silikon karbida dan titanium nitrida serta asid nitrit dengan kepekatan $3-5 \%$ telah berjaya mengekstrak sebahagian $\mathrm{Pb}$ daripada permukaan kaca yang dihancurkan (Erzat \& Zhang 2014). Seterusnya, kaedah pengkapsulasi, pengklorinanpenguapan dan mekano-kimia juga telah digunakan untuk mengekstrak $\mathrm{Pb}$ dan unsur berbahaya dalam kaca CRT (Hu et al. 2015; Zhang et al. 2013). Walau bagaimanapun, kaedah ini mempunyai beberapa kekurangan seperti pengekstrakan $\mathrm{Pb}$ yang rendah dan kos operasi yang tinggi.

\section{PEMERHATIAN FIZIKAL SISA KACA PEGUN}

Pemerhatian fizikal ke atas semua bentuk akhir sisa kaca telah dijalankan dengan menggunakan mata kasar dan diringkaskan dalam Jadual 3. Sisa kaca pegun dengan komposisi $20 \%$ bt. EC dan $80 \%$ bt. CRT kelihatan berwarna kehijauan, manakala sampel berkomposisi $25 \%$ bt. EC dan $75 \%$ bt. CRT pula berwarna kelabu jernih. Permukaan kedua-dua sampel tidak berkilat dan kasar serta terdapat butiran hitam di permukaan sampel. Ini berkemungkinan sisa enap cemar minyak tidak bercampur dengan kaca CRT secara sekata dan pembakaran tidak lengkap berlaku pada suhu tersebut.

JADUAL 3. Pemerhatian fizikal terhadap pelbagai komposisi dan suhu yang berbeza

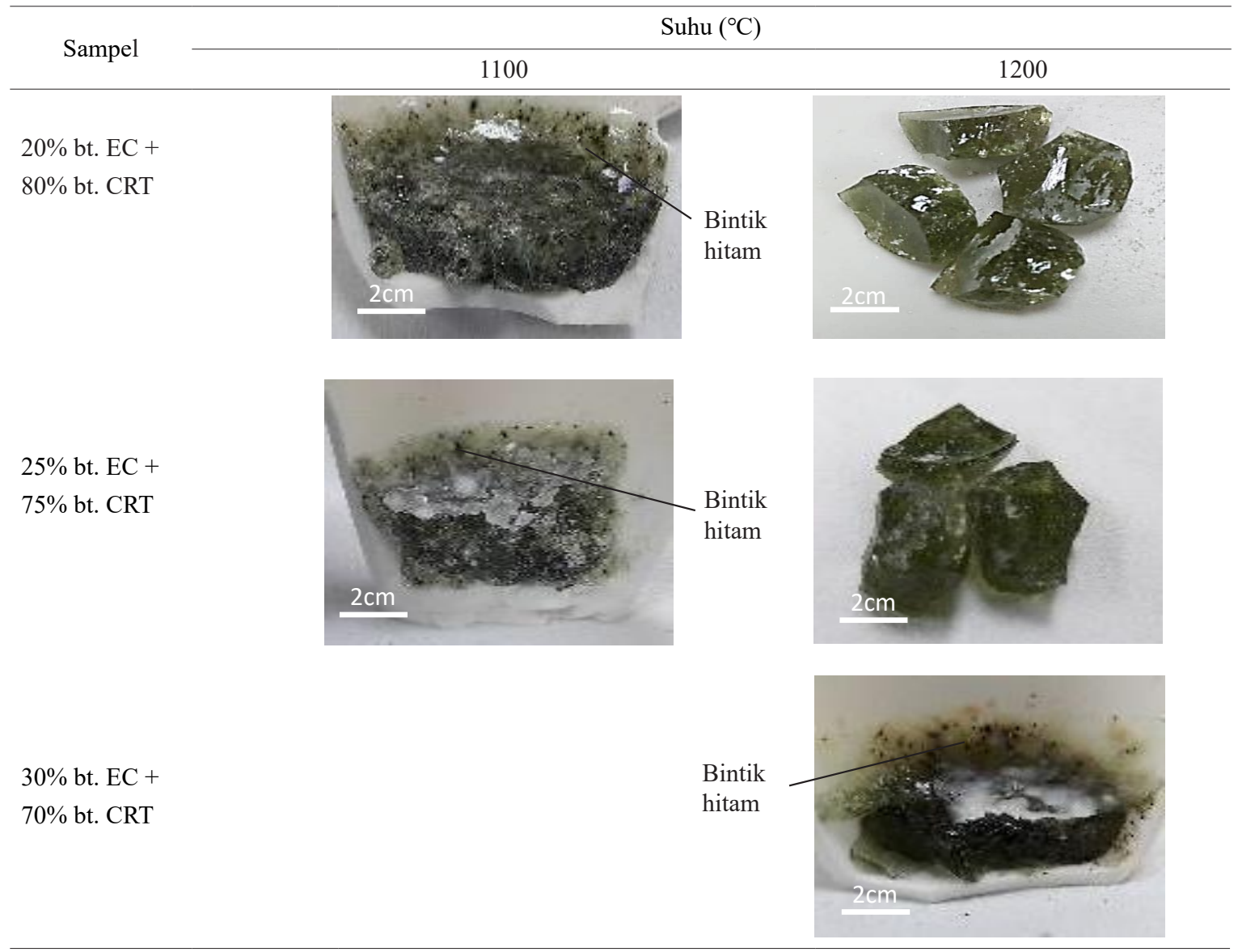


Komposisi sisa kaca pegun masing-masing 20\% bt. EC dan $80 \%$ bt. CRT, dan $25 \%$ bt. EC dan $75 \%$ bt. CRT, dibakar pada suhu yang lebih tinggi, iaitu $1200^{\circ} \mathrm{C}$ telah menghasilkan sampel yang homogen seperti dalam Jadual 3 berbanding sampel pada suhu $1100^{\circ} \mathrm{C}$. Permukaan sampel yang dibakar pada suhu lebih tinggi kelihatan licin dan bersinar serta menghasilkan sampel yang berwarna hijau jernih berbanding sampel yang dibakar pada suhu rendah. Selain itu, butiran hitam juga tidak kelihatan pada sampel yang dibakar pada suhu $1200^{\circ} \mathrm{C}$ tersebut. Ini jelas menunjukkan bahawa sisa enap cemar minyak bercampur dengan sekata dan berlakunya pembakaran lengkap. Ini menunjukkan sisa kaca CRT juga mencair sepenuhnya semasa proses pembakaran kerana takat lebur kaca CRT adalah $700^{\circ} \mathrm{C}$. Namun, pada suhu yang sama iaitu $1200^{\circ} \mathrm{C}$, sampel tidak bercampur dengan sekata dengan peningkatan beban sisa enap cemar $(30 \%$ bt.) dalam sampel dan tidak berlaku pembakaran lengkap kerana masih terdapat butiran hitam pada permukaan sampel. Pemerhatian yang sama dapat dilihat dalam kajian lepas dengan peningkatan beban sisa dalam sisa kaca pegun boleh memberi kesan kepada integriti sisa kaca pegun disebabkan kehadiran hablur (Mohd Fadzil et al. 2015). Namun, ia juga mungkin memberi kesan positif sekiranya fasa hablur tersebut turut menjadi perisai agar unsur radioaktif yang berbahaya tidak melarut lesap daripada bentuk sisa yang dihasilkan.

Oleh itu, sampel yang dibakar pada suhu $1200^{\circ} \mathrm{C}$ menunjukkan pencampuran sisa enap cemar dan kaca CRT adalah sekata berbanding pembakaran pada suhu $1100^{\circ} \mathrm{C}$. Ini dipengaruhi oleh kekurangan haba yang mencukupi untuk menghubungkan komposisi kaca dan kandungan enap cemar minyak dalam jaringan bentuk sisa kaca pegun. Komposisi $25 \%$ bt. EC merupakan muatan sisa enap cemar minyak yang optimum pada suhu $1200^{\circ} \mathrm{C}$ untuk menghasilkan bentuk sisa kaca pegun yang terbaik berbanding komposisi lain.

\section{PEMBELAUAN SINAR-X (XRD)}

Analisis XRD ini dilakukan bertujuan untuk menentukan kehadiran fasa hablur yang terhasil pada sisa akhir kaca pegun. Perubahan fasa, komposisi unsur dan sifat kehabluran sampel dapat diketahui melalui analisis ini. Julat pembelauan yang dikaji ialah $0-80^{\circ}$. Sebanyak $5 \%$ anatase $\left(\mathrm{TiO}^{2}\right)$ ditambah ke dalam sampel, yang bertindak sebagai piawai tambahan dalam analisis ini (Mohd Fadzil et al. 2015).

Spektrum XRD yang terhasil bagi kesemua sampel pada suhu $1100^{\circ} \mathrm{C}$ dan $1200^{\circ} \mathrm{C}$, menunjukkan keadaan sampel yang amorfus telah dirumuskan dalam Rajah 1. Semua sampel hanya menunjukkan puncak hablur piawai $\mathrm{TiO}_{2}$ yang ditambah ke dalam sampel. Keputusan ini disokong oleh kajian lepas dengan bentuk sisa kaca yang terdiri daripada kaca CRT juga menghasilkan fasa amorfus (Galvao et al. 2015). Manakala, pembentukan gelas seramik yang terdiri daripada campuran abu terbang lignit dan sanga keluli relau bagas juga menghasilkan penghabluran yang amorfus pada suhu yang tinggi (Karamberi \& Moutsatsou 2004) dengan menunjukkan ketahanan kimia dan larut lesap yang tinggi. Pembentukan pepejal hablur dalam struktur kaca amorfus boleh dipengaruhi oleh faktor kadar penyejukan semasa proses pengacaan, komposisi kaca dan kandungan sisa radioaktif yang terkandung di dalamnya (Ojovan 2008).

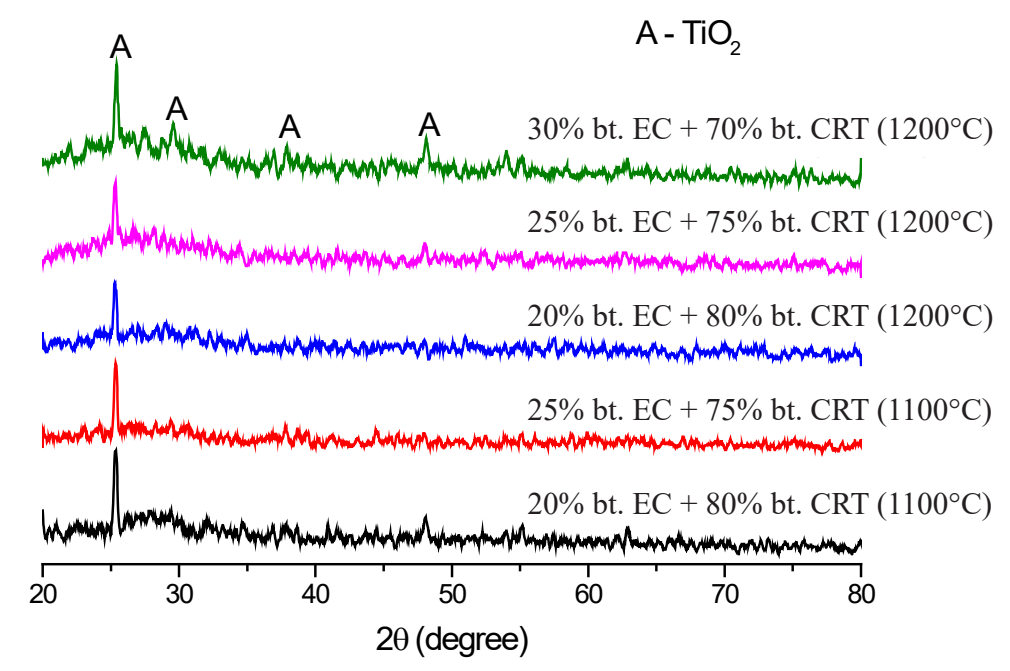

RAJAH 1. Analisis XRD bagi kesemua sampel pada suhu $1100^{\circ} \mathrm{C}$ dan $1200^{\circ} \mathrm{C}(\%$ mewakili berat $)$ 
PENENTUAN MORFOLOGI PERMUKAAN SISA KACA

Analisis FESEM-EDX bertujuan melihat morfologi permukaan bentuk sisa kaca dan pemetaan unsur dominan yang terdapat dalam sampel akhir. Sampel dengan komposisi $20 \%$ bt. EC dan $80 \%$ bt. CRT pada suhu $1200^{\circ} \mathrm{C}$, telah dipilih bagi menjalani analisis ini disebabkan bentuk sisa kaca yang terhasil dalam keadaan homogen dan berlakunya pembakaran lengkap.

Rajah 2 menunjukkan morfologi dan pemetaan taburan unsur $(\mathrm{O}, \mathrm{Si}, \mathrm{Pb}, \mathrm{Na}$ dan $\mathrm{Ca})$ adalah sekata.
Manakala, spektrum EDX yang diringkaskan dalam Jadual 4, menunjukkan peratusan $\mathrm{O}$ adalah paling tinggi (42.1\% bt.), diikuti oleh Si (22.7\% bt.), Pb (15.7\% bt.) dan B (5.2\% bt.) yang merupakan unsur yang dominan yang terkandung dalam sampel. Unsur lain seperti K, $\mathrm{Na}, \mathrm{Al}, \mathrm{Ca}, \mathrm{Mg}, \mathrm{U}$, dan Th juga dikesan dengan peratusan yang kecil ( $<5 \%$ bt.). Hasil ini menunjukkan bahawa tiada fasa yang dikesan yang diperkaya dengan unsur tertentu.
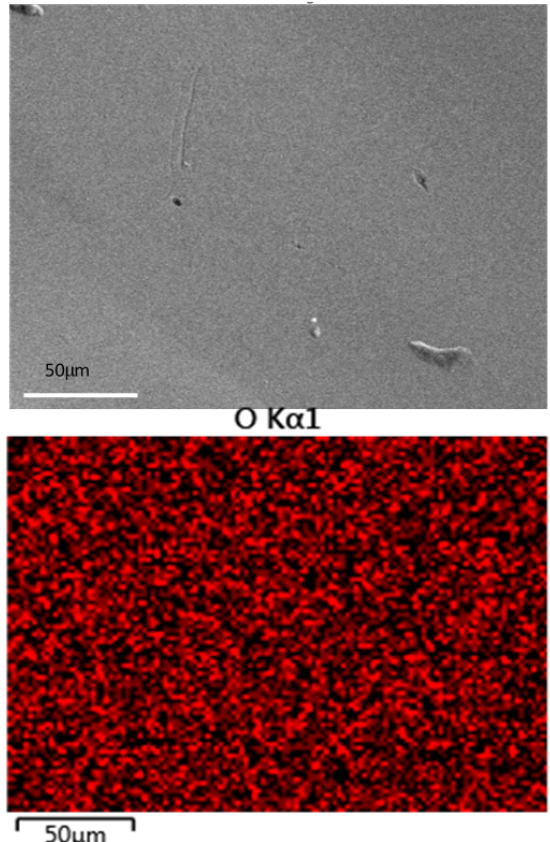

$\mathrm{Pb} \mathrm{M} \alpha 1$

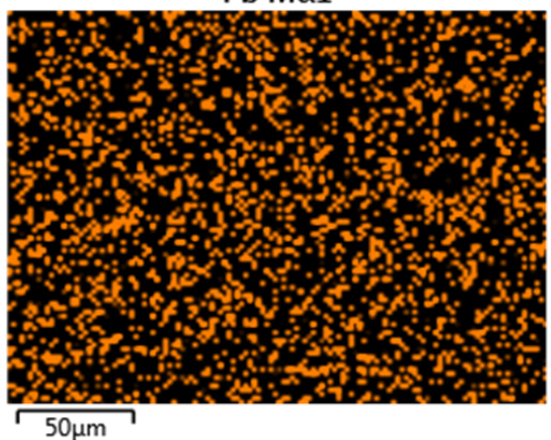

Si $K \alpha 1$

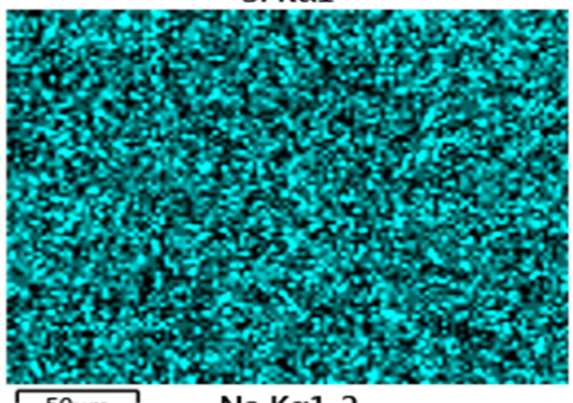

$\mathrm{Na} \mathrm{K} \alpha 12$

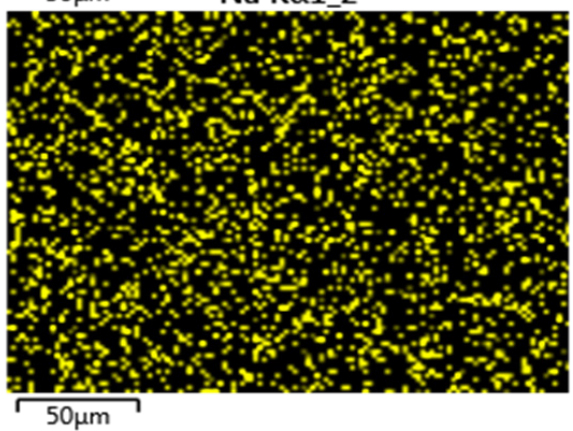

Ca $K \alpha 1$

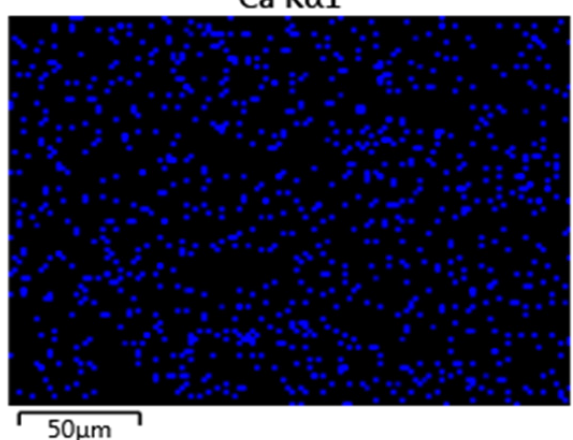

RAJAH 2. Pemetaan unsur dalam sampel $20 \%$ bt. EC dan $80 \%$ bt. CRT pada suhu $1200^{\circ} \mathrm{C}$ 
JADUAL 4. Peratusan unsur yang diperoleh daripada spektrum EDX

\begin{tabular}{cc}
\hline Unsur & $\%$ bt. \\
\hline $\mathrm{O}$ & 42.1 \\
$\mathrm{Si}$ & 22.7 \\
$\mathrm{~Pb}$ & 15.7 \\
$\mathrm{~B}$ & 5.2 \\
$\mathrm{~K}$ & 4.1 \\
$\mathrm{Na}$ & 4.0 \\
$\mathrm{Al}$ & 2.7 \\
$\mathrm{Ca}$ & 2.0 \\
$\mathrm{Mg}$ & 1.0 \\
$\mathrm{U}$ & 0.4 \\
$\mathrm{Th}$ & 0.1 \\
\hline
\end{tabular}

Walaupun begitu, terdapat kehadiran hablur yang dapat dilihat di kawasan lain permukaan kaca. Rajah 3 menunjukkan morfologi permukaan sampel dengan 10,000 kali pembesaran yang menunjukkan kehadiran hablur halus. Hablur yang kelihatan berbentuk seperti kumpulan jarum halus dengan panjang kurang dari $2 \mu \mathrm{m}$. Kehadiran hablur ini tidak dapat dikesan melalui ujian XRD disebabkan saiznya yang sangat halus dan tidak tertabur secara sekata.

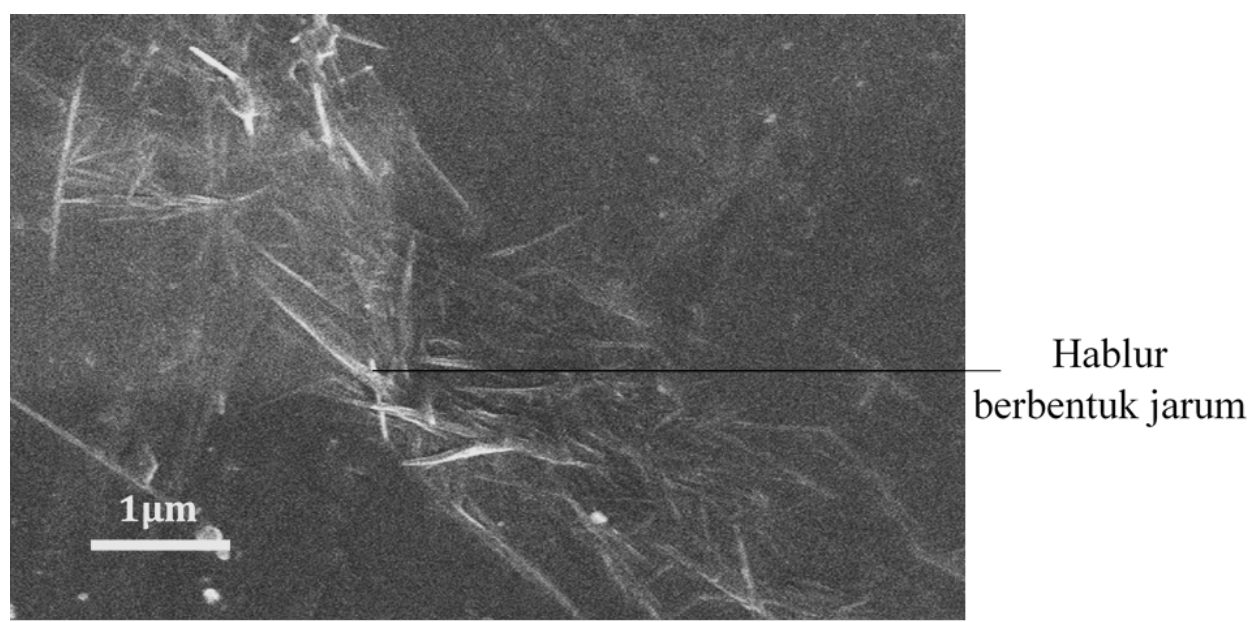

RAJAH 3. Struktur hablur halus yang terdapat dalam sisa kaca pegun ( $20 \%$ bt. EC dan $80 \%$ bt. CRT) pada suhu $1200^{\circ} \mathrm{C}$ 
Berbanding dengan kajian lepas yang menggunakan perumah kaca berbeza bagi sisa radioaktif yang berbeza, kehadiran hablur oksiapatit $\left(\mathrm{Ca}_{2} \mathrm{RE}_{8} \mathrm{Si}_{6} \mathrm{O}_{26}\right)$, cerianit $\left(\mathrm{CeO}_{2}\right)$ dan kompleks hablur (campuran borosilikat-Ce, mulit dan korundum) (Mohd Fadzil et al. 2015) dan hablur monazit $\left(\mathrm{Ce}\left(\mathrm{PO}_{4}\right)\right.$ ) (Liu et al. 2018) dapat dilihat dengan jelas. Manakala, kehadiran hablur $\mathrm{Pb}$ dan $\mathrm{Ca}$ secara sekata dan homogen dilaporkan dalam kajian Gignozzi et al. (2015), namun kandungan Pb tidak dapat dilaporkan semasa pemetaan EDX dilakukan kerana kepekatannya yang terlalu rendah untuk dikesan.

\section{UJIAN KETAHANAN KIMIA SISA KACA PEGUN}

Air ternyahion telah digunakan sebagai larutan bagi proses larut resap. Nilai $\mathrm{pH}$ larutan sebelum proses larut resap dilakukan adalah 7 . Selepas 7 hari, nilai $\mathrm{pH}$ larutan didapati meningkat. Hal ini berlaku disebabkan air ternyahion bertindak balas dengan ion beralkali pada tapak oksigen bukan penghubung untuk menghasilkan ikatan hidroksil serta membebaskan ion beralkali ke dalam larutan sehingga menyebabkan berlaku peningkatan $\mathrm{pH}$ pada larutan (Jain 2019). Nilai pH larutan bagi semua sampel ditunjukkan dalam Jadual 5.

JADUAL 5. Nilai pH selepas proses larut lesap dijalankan

\begin{tabular}{|c|c|c|}
\hline \multirow{2}{*}{ Sampel } & \multicolumn{2}{|c|}{ Nilai pH } \\
\hline & $1100^{\circ} \mathrm{C}$ & $1200^{\circ} \mathrm{C}$ \\
\hline $20 \%$ bt. $\mathrm{EC}+80 \%$ bt. CRT & $9.26 \pm 0.005$ & $9.35 \pm 0.005$ \\
\hline $25 \%$ bt. $\mathrm{EC}+75 \%$ bt. $\mathrm{CRT}$ & $9.30 \pm 0.002$ & $9.42 \pm 0.002$ \\
\hline $30 \%$ bt. $\mathrm{EC}+70 \%$ bt. $\mathrm{CRT}$ & - & $9.06 \pm 0.042$ \\
\hline
\end{tabular}

Pembebasan ternormal bagi unsur $\mathrm{B}, \mathrm{Si}$ dan $\mathrm{Na}$ dihitung menggunakan persamaan (2) dan direkodkan dalam Jadual 6. Sisihan piawai dihitung berdasarkan purata sampel sama yang diulangi. Pada suhu $1100^{\circ} \mathrm{C}$, kedua-dua sampel menunjukkan pelepasan ion yang lebih tinggi, begitu juga dengan sampel 30\% bt. enap cemar minyak yang dibakar pada suhu $1200^{\circ} \mathrm{C}$. Hal ini boleh dipengaruhi oleh faktor seperti perbezaan komposisi kaca dan ujian persekitaran (suhu, perubahan $\mathrm{pH}$ larutan berlaku disebabkan oleh jumlah proton yang digunakan dan nisbah permukaan isipadu) (Kim et al. 2020; Ojovan et al. 2004). Jika dibandingkan antara semua sampel, sampel bentuk sisa kaca yang homogen merekodkan pelepasan ion yang lebih rendah. Keadaan ini menggambarkan bahawa dengan mendapatkan bentuk sisa kaca yang homogen tanpa hablur tidak menggugat integriti bentuk sisa kaca tersebut malah ketahanan kimia semakin tinggi. Jika semakin tinggi pelepasan ion alkali dalam larutan, maka kebolehan kaca sebagai medium penyimpanan sisa radioaktif semakin kurang (Jain 2019). 
JADUAL 6. Pembebasan ternormal $\left(\mathrm{g} / \mathrm{m}^{2}\right)$ bagi unsur B, Na dan Si pada komposisi dan suhu yang berbeza

\begin{tabular}{ccccc}
\hline Sampel & & \multicolumn{3}{c}{ Pembebasan ternormal $\left(\mathrm{g} / \mathrm{m}^{2}\right)$} \\
\cline { 3 - 4 } & Suhu $\left({ }^{\circ} \mathrm{C}\right)$ & $\mathrm{B}$ & $\mathrm{Na}$ & $\mathrm{Si}$ \\
\cline { 3 - 4 } $20 \%$ bt. EC $+80 \%$ bt. CRT & 1100 & $0.0381 \pm 0.0008$ & $0.0631 \pm 0.0005$ & $0.1403 \pm 0.0002$ \\
$25 \%$ bt. EC $+75 \%$ bt. CRT & 1100 & $0.0403 \pm 0.0004$ & $0.0738 \pm 0.0001$ & $0.1457 \pm 0.0003$ \\
$20 \%$ bt. EC $+80 \%$ bt. CRT & 1200 & $0.0176 \pm 0.0005$ & $0.0518 \pm 0.0004$ & $0.0414 \pm 0.0002$ \\
$25 \%$ bt. EC $+75 \%$ bt. CRT & 1200 & $0.0454 \pm 0.0005$ & $0.0916 \pm 0.0001$ & $0.0887 \pm 0.0005$ \\
$30 \%$ bt. EC $+70 \%$ bt. CRT & 1200 & $0.0221 \pm 0.0007$ & $0.1190 \pm 0.0001$ & $0.1589 \pm 0.0012$ \\
\hline
\end{tabular}

Pada suhu $1200^{\circ} \mathrm{C}$, sampel dengan muatan sisa $20 \%$ bt. dan $25 \%$ bt. enap cemar minyak menunjukkan pelepasan ion yang lebih rendah, mungkin disebabkan berlakunya campuran sisa enap cemar serta kaca yang sekata semasa proses pembakaran, dengan kesemua komponen sisa enap cemar telah menjadi sebahagian daripada sktruktur kaca tersebut. Hasil ini menyokong hasil melalui pemerhatian fizikal yang menunjukkan bahawa bentuk sisa kaca yang homogen seperti komposisi masing-masing $25 \%$ bt. enap cemar minyak dan $75 \%$ bt. kaca CRT dan $20 \%$ bt. enap cemar minyak dan $80 \%$ bt. kaca CRT pada suhu $1200^{\circ} \mathrm{C}$ boleh menjadi calon komposisi terbaik untuk sisa enap cemar minyak ini.

Ini boleh dipengaruhi oleh struktur kaca yang bergantung kepada kandungan pengubah dan rangkaian pembentuk, yang akan menentukan ketahanan sesuatu kaca tersebut. Hal ini disebabkan berlakunya interaksi permukaan kaca dengan atmosfera (sama ada melalui bahan kimia atau fizikal) yang boleh mengubah sifat struktur kaca secara keseluruhannya. Perubahan struktur sisa kaca pegun berlaku apabila bersentuhan dengan air dan menyebabkan tindak balas, iaitu seperti berikut (Kim et al. 2011; Sandgren 2019): Proses penghidratan berlaku apabila molekul air meresap masuk ke dalam struktur kaca melalui ruang bebas. Jika semakin banyak ruang bebas yang terdapat dalam struktur kaca, maka makin cepat kadar penghidratan berlaku; Proses pertukaran ion untuk membebaskan logam beralkali, yang melibatkan pertukaran hidrogen ion daripada molekul air dengan logam beralkali $\left(\mathrm{M}^{+}\right)$. Persamaan tindak balas seperti (3) berikut:

$$
(=\mathrm{Si}-\mathrm{O}-\mathrm{M})_{\text {glass }}+\mathrm{H}^{+} \leftrightarrow(\equiv \mathrm{Si}-\mathrm{O}-\mathrm{H})_{\text {glass }}+\mathrm{M}^{+}
$$

Tindak balas ini akan mewujudkan permukaan gel silika yang kebiasaannya mempunyai ketebalan berukuran $0.1 \mu \mathrm{m}$ dan menghasilkan produk tindak balas yang terkumpul di permukaan serta meningkatkan pembubaran struktur sisa kaca. Kadar pertukaran ion bergantung kepada struktur kaca dan komposisi kimia sekeliling; Proses hidrolisis merupakan tindak balas air dengan ikatan logam-oksigen untuk membentuk kumpulan hidroksil serta mengubah struktur kaca. Persamaan tindak balas seperti (4) berikut:

$$
(\equiv \mathrm{Si}-\mathrm{O}-\mathrm{Si} \equiv)_{\text {glass }}+\mathrm{H}_{2} \mathrm{O} \leftrightarrow 2 \mathrm{HO}-\mathrm{Si} \equiv
$$


Tindak balas ini menyebabkan berlakunya penurunan daya tahan kaca akibat daripada perubahan kelikatan permukaan dan meningkatkan kemungkinan kaca pecah.

Kajian ini juga menunjukkan kadar pembebasan ternormal adalah lebih perlahan berbanding ujian ketahanan kimia yang dijalankan oleh Bibler dan Jantzen (1989) terhadap sisa kaca yang mengandungi sisa radioaktif aras tinggi dengan kepekatan $\mathrm{B}, \mathrm{Na}$ dan $\mathrm{Si}$ masing-masing ialah $1.14,1.01 \mathrm{dan} 0.44 \mathrm{~g} / \mathrm{m}^{2}$. Pembebasan komponen $\mathrm{B}$ dan $\mathrm{Na}$ dalam Jadual 6 bagi kajian ini adalah lebih rendah berbanding kajian lepas (Mohd Fadzil et al. 2015) dan kaca daripada piawai penilaian sekitaran yang mencatatkan julat $5.36-8.35 \mathrm{~g} / \mathrm{m}^{2}$ dan 4.28-7.61 g/ $\mathrm{m}^{2}$ masing-masing bagi B dan $\mathrm{Na}$ (Crum et al. 2009; Peeler et al. 2000; Youchak-Billings et al. 2008). Manakala, kaca borosilikat yang mengandungi $\mathrm{Na}$ yang tinggi, K-26 menunjukkan kadar pembebasan ternormal $\mathrm{Na}, \mathrm{B}$ dan Si adalah masing-masing 0.06, 0.04 dan 0.03 $\mathrm{g} / \mathrm{m}^{2} /$ hari (Ojovan et al. 2004). Pembebasan ternormal dalam kajian ini masih di bawah julat $2 \mathrm{~g} / \mathrm{m}^{2}$ yang kebiasaannya dijadikan penanda aras untuk pengukuran ini (Mohd Fadzil et al. 2015). Sebagai rekod bagi kajian ini, pembebasan ternormal bagi unsur berbahaya iaitu $\mathrm{U}$, Th dan $\mathrm{Pb}$ juga adalah terlalu kecil $\left(<0.0001 \mathrm{~g} / \mathrm{m}^{2}\right)$. Ini menunjukkan kaca CRT sesuai digunakan dalam proses pemegunan sisa radioaktif aras rendah, tidak berbahaya dan selamat terhadap alam sekitar serta boleh diguna pakai dalam menyelesaikan masalah pelupusan sisa enap cemar di Malaysia.

\section{KESIMPULAN}

Kajian ini mendapati bahawa teknik pengacaan sesuai digunakan bagi memerangkap bahan bertoksik dan NORM yang terkandung di dalam sisa enap cemar minyak serta selamat kepada alam sekitar. Jadi, komposisi beban sisa yang optimum bagi enap cemar minyak dengan menggunakan kaca CRT berada dalam julat antara 20$25 \%$ bt. yang dibakar pada suhu $1200^{\circ} \mathrm{C}$. Keputusan menunjukkan bahawa sampel dalam komposisi ini adalah homogen, bercampur dengan sekata dan berlakunya pembakaran yang lengkap semasa proses pengacaan dijalankan. Majoriti sampel yang terhasil juga berada dalam keadaan amorfus dan unsur seperti $\mathrm{Si}, \mathrm{O}, \mathrm{Na}$ dan $\mathrm{Ca}$ bertabur dengan sekata. Pembebasan ternormal juga adalah rendah berbanding kajian lepas dan kaca daripada piawai penilaian sekitaran.

\section{PENGHARGAAN}

Penyelidik mengucapkan terima kasih kepada Universiti Kebangsaan Malaysia atas geran yang diberikan bagi melaksanakan projek ini (GUP-2017-108). Penyelidik juga mengucapkan terima kasih kepada pihak yang terlibat dengan kajian ini secara langsung atau tidak langsung.

\section{RUJUKAN}

Amran, A.M., Muhammad, P.A., Abdul, H.S., Kamaruzaman, S. \& Mohd, N.Y. 2000. Radioactivity analysis of 226-Ra, 228-Ra and element concentrations in petroleum sludge samples in Malaysia. The Malaysian Journal of Analytical Sciences 6: 173-177.

ASTM. 2002. C1285-02 Standard Test Methods for Determining Chemical Durability of Nuclear, Hazardous, and Mixed Waste Glasses and Multiphase Glass Ceramics: The Product Consistency Test (PCT). West Conshohocken, PA: American Society for Testing and Materials (ASTM).

Bibler, N.E. \& Jantzen, C.M. 1989. The product consistency test and its role in the waste acceptance process for DWPF glass. Journal of Waste Management 22(3): 743-749.

Crum, J.V., Billings, A.L., Lang, J., Marra, J.C., Rodriguez, C., Ryan, J.V. \& Vienna, J.D. 2009. Baseline Glass Development for Combined Fission Products Waste Streams. Richland, Washington D.C.: United States Department of Energy.

Erzat, A. \& Zhang, F.S. 2014. Evaluation of lead recovery efficiency from waste CRT funnel glass by chlorinating volatilization process. Environmental Technology 35(22): 2274-2780.

Fernandes, H.R., Andreola, F., Barbieri, L., Lancellotti, I., Pascual, M.J. \& Ferreira, J.M.F. 2013. The use of eggshells to produce cathode ray tube (CRT) glass foams. Ceramics International 39(8): 9071-9078.

Gallego, J.L.R., Garcia-Martinez, M.J., Llamas, J.F., Belloch, C., Pelaez, A.I. \& Sanchez, J. 2007. Biodegradation of oil tank bottom sludge using microbial consortia. Biodegradation 18(3): 269-281.

Galvao, A.C.P., Farias, A.C.M. \& Mendes, J.U.L. 2015. Characterization of waste of soda-lime glass generated from lapping process to reuse as filler in composite materials as thermal insulation. Ceramica 61(359): 367-373.

Gignozzi, M.C., Saccani, A., Barbieri, L. \& Lancellotti, I. 2015. Glass waste as supplementary cementing materials: The effects of glass chemical composition. Cement and Concrete Composites 55: 45-52.

Hu, B., Zhao, S. \& Zhang, S. 2015. Removal of lead from cathode ray tube funnel glass by generating the sodium silicate. Journal of the Air \& Waste Management Association 65(1): 106-114. 
International Association of Oil and Gas Producers (IOGP). 2016. Managing Naturally Occurring Radioactive Material (NORM) in Oil and Gas Industry. Cardiff: IOGP Publication Library.

Jain, V. 2019. Chemical Durability of Nuclear Waste Glasses A Review. Center for Nuclear Waste Regulatory Analyses, Southwest Research Institute. San Antonio, Texas: United States Nuclear Regulatory Commission. https://www.nrc. gov/docs/ML0613/ML061310303.pdf. Diakses pada 6 Jun 2019.

Karaahmet, O. \& Cicek, B. 2019. Waste recycling of cathode ray tube glass through industrial production of transparent ceramic frits. Journal of the Air and Waste Management Association 69(10): 1258-1266.

Karamberi, A. \& Moutsatsou, A. 2004. Characterization of glass and glass-ceramics obtained from industrial by-products. In Waste Management and the Environment II, edited by Popov, V., Itoh, H., Brebbia, C.A. \& Kungolos, S. Ashurst, Southampton: WIT Press. m.s. 377-385.

Keshavarzifard, M., Zakaria, M.P., Hwai, T.S., Yusuff, F.M., Mustafa, S., Vaezzadeh, V., Magam, S.M., Masood, N., Alkhadher, S.A.A. \& Abootalebi-Jahromi, F. 2014. Baseline distribution and sources of polycyclic aromatic hydrocarbons (PAHs) in the surface sediments from the Prai and Malacca Rivers, Peninsular Malaysia. Marine Pollution Bulletin 88(1-2): 366-372.

Kim, C.W., Park, J.K. \& Hwang, T.W. 2011. Analysis of leaching behavior of simulated LILW glasses by using the MCC-1 test method. Journal of Nuclear Science and Technology 48(7): 1108-1114.

Kim, M., Kim, H.G., Kim, S., Yoon, J.H., Sung, J.Y., Jin, J.S., Lee, M.H., Kim, C.W., Heo, J. \& Hong, K.S. 2020. Leaching behaviors and mechanisms of vitrified forms for the low-level radioactive solid wastes. Journal of Hazardous Materials 384: 121296.

Liu, X., Yao, T., Lai, R., Xiu, J., Huang, L., Sun, S., Luo, Y., Song, Z. \& Zhang, Z. 2019. Recovery of crude oil from oily sludge in an oilfield by sophorolipid. Petroleum Science and Technology 37(13): 1582-1588.

Liu, X., Qiao, Y., Qian, Z. \& Ma, H. 2018. Research on chemical durability of iron phosphate glass wasteforms vitrifying $\mathrm{SrF}_{2}$ and $\mathrm{CeF}_{3}$. Journal of Nuclear Materials 508: 286-291.

Malaysian Investment Development Authority. 2015. Minyak dan Gas. http://www.mida.gov.my/home/oil-and-gas/ posts/?lg=MAL. Diakses pada 7 Mei 2019.

Meor, Y.M.S., Hishamuddin, H. \& Thye, F.C. 2007. Characterization study of oil sludge and sediment. Journal of Nuclear and Related Technology 4: 25-28.

Mohamad Puad, H.A. \& Muhd Noor, M.Y. 2003. Behaviours of Th-232, U-238, Ra-228 and Ra-226 on combustion of crude oil terminal sludge. Journal of Environmental Radioactivity 73(3): 289-305.
Mohd Fadzil, S., Pavel, H., Michael, J.S. \& Brian, J.R. 2015. Liquidus temperature and chemical durability of selected glasses to immobilize rare earth oxides waste. Journal of Nuclear Materials 465(3): 657-663.

Mohd Fadzil, S., Sarmani, S., Majid, A.A., Khoo, K.S. \& Hamzah, A. 2011. $k_{0}$-INAA measurement of levels of toxic elements in oil sludge and their leachability. Journal of Radioanalytical and Nuclear Chemistry 287: 41-47.

Ojovan, M.I. 2008. Viscosity and glass transition in amorphous oxides. Advances in Condensed Matter Physics 2008: 817829.

Ojovan, M.I. \& Batyukhnova, O.G. 2007. Glasses for nuclear waste immobilization. 2007 Waste Management Symposium. Tucson, Arizona: International Atomic Energy Agency. m.s. $1-15$.

Ojovan, N.V., Startceva, L.V., Barinov, A.S., Ojovan, M.I., Bacon, D.H., McGrail, B.P. \& Vienna, J.D. 2004. Product consistency test of fully radioactive high-sodium content borosilicate glass K-26. Materials Research Society Symposium Proceedings 824. Cambridge, United Kingdom: Cambridge University Press. m.s. 1-6.

Omar, M. 2019. NORM Waste Management in Malaysia. https://inis.iaea.org/collection/NCLCollectionStore/ Public/31/016/31016206.pdf?r=1\&r=1. Diakses pada $2 \overline{1}$ Jun 2019.

Omar, M., Ali, H.M., Abu, M.P., Kontol, K.M., Ahmad, Z., Ahmad, S.H.S.S., Sulaiman, I. \& Hamzah, R. 2004. Distribution of radium in oil and gas industry wastes from Malaysia. Applied Radiation and Isotopes 60: 779-782.

Peeler, D., Edwards, T.B., Reamer, I.A., Vienna, J.D., Smith, D.E., Schweiger, M.J., Riley, B.J. \& Crum, J.V. 2000. Composition/Property Relationships for the Phase $1 \mathrm{Am} /$ Cm Glass Variability Study. Richland, Washington D.C.: United States Department of Energy.

Sandgren, E. 2019. Leaching of glass waste - structure and humidity cell tests. Professional Degree Thesis. Department of Earth Sciences, Uppsala University (Unpublished).

Suganya, K., Sivapragasam, C., Sharma, N.K. \& Vanitha, S. 2019. Current trends on oil sludge characterization, toxicity and treatment systems. International Journal of Recent Technology and Engineering 8(4S2): 13-17.

UKEssays. 2018. The Brief History and Background of Petronas. https://www.ukessays.com/essays/business/ the-brief-history-and-background-of-petronas-businessessay.php?vref=1. Diakses pada 11 Ogos 2020.

United States Department of Agriculture. 2018. Determination of metals by ICP-MS and ICP-OES. https://www.fsis. usda.gov/wps/wcm/connect/b9a63ea1-cae9-423b-b20036a47079ae49/CLG-TM3.pdf?MOD=AJPERES. Diakses pada 13 Ogos 2020. 
Yot, P.G. \& Mear, F.O. 2011. Characterization of lead, barium and strontium leachability from foam glasses elaborated using waste cathode ray tube glasses. Journal of Hazardous Materials 185(1): 236-241.

Youchak-Billings, A.L., Crum, J.V., Marra, J.C., Riley, B.J., Vienna, J.D. \& Edmondson, A. 2008. Waste/storage form baseline-fission products \& lanthanides. Richland, Washington D.C.: United States Department of Energy.

Zaidan, J.A.R. 2010. Natural occurring radioactive material (NORM) in the oil and gas industry. Journal of Petroleum Research \& Studies 1(1): 4-21.

Zhang, C., Wang, J., Bai, J., Guan, J., Wu, W. \& Guo, C. 2013. Recovering lead from cathode ray tube funnel glass by mechano-chemical extraction in alkaline solution. Waste Management and Research 31(7): 759-763.

Nur Syuhada Izzati Ruzali, Nurshahirah Alwi, Mohd Idzat Idris \& Syazwani Mohd Fadzil*

Jabatan Fizik Gunaan

Fakulti Sains dan Teknologi

Universiti Kebangsaan Malaysia

43600 UKM Bangi, Selangor Darul Ehsan

Malaysia
Mohd Idzat Idris \& Syazwani Mohd Fadzil* Pusat Penyelidikan Teknologi Nuklear

Fakulti Sains dan Teknologi

Universiti Kebangsaan Malaysia

43600 UKM Bangi, Selangor Darul Ehsan

Malaysia

Rohyiza Ba'an

Jabatan Teknologi Sisa dan Persekitaran

Agensi Nuklear Malaysia

43000 Kajang, Selangor Darul Ehsan

Malaysia

*Pengarang untuk surat-menyurat; email: syazwanimf@ukm. edu.my

Diserahkan: 11 September 2020

Diterima: 15 Disember 2020 